\title{
Multi-layer agility: a proposed concept of business agility in organizational behavior perspective
}

\author{
Nopriadi Saputra ${ }^{1}$, Endang Chumaidah², and Riza Aryanto ${ }^{3}$ \\ ${ }^{1}$ Management Department, BINUS Business School, Bina Nusantara University, Indonesia \\ ${ }^{2}$ Industrial Engineering, Telkom University, Indonesia \\ ${ }^{3}$ PPM School of Management, Indonesia
}

\begin{abstract}
Turbulence in the business environment imposed large companies or market leaders to become more agile in doing business. Developing business agility can be implemented in many levels of business organization. This paper proposes a multi-layer perspective of business agility construct by examining construct validity through structural equation modelling. Based on organizational behavior theory, this paper proposes combining construct from three different perspectives of business agility: strategic agility from an organizational perspective, leadership agility from a group perspective, and learning agility from an individual perspective. The paper involved 477 supervisors and managers of Indonesian oil palm plantations as respondents. The data was analyzed by using Lisrel version 9.30. The result explains that the second-order construct is the best-fit construct for defining multi-layer agility as a measurement model.
\end{abstract}

\section{INTRODUCTION}

Besides providing easiness to cooperate with various parties and offering many opportunities to innovate, the utilization of internet technology also increases the complexity of doing business. Internet technology brings the world into the Industry 4.0 era and makes the world increasingly volatile, uncertain, complex, and ambiguous (Bawany,2016; Mack \& Khare,2015; Murthy \& Murthy, 2014). Turbulence in the business environment affects business viability negatively (Glauner,2016). Therefore, every company is imposed to adapt quickly, even faster than the change itself. Large companies or market leaders are imposed to become more flexible and agile in doing business (Cannon \& Elford, 2017; Evans, 2002; Heisterberg \& Verma, 2014; Hugos, 2009; McCann, Selsky, \& Lee, 2009).

McCann \& Selsky (2012) explains that there are three types of business environment changes, namely: (1) episodic changes, (2) continuous changes, and (3) disruptive changes. Each type of change requires different dynamic capabilities. Episodic changes require organizational flexibility, continuous changes require organizational agility and disruptive changes require organizational resilience. This paper focuses the discussion on the business agility in dealing with continuous changes. There are many themes in various contexts related to business agility that previous researchers have discussed. The business agility themes in the organizational context are organizational agility (Crocitto \& Youssef,2003), corporate agility (Brown \& Agnew, 1982), strategic agility (Doz \& Kosonen,2010), and enterprise agility (Tsourveloudis \& Valavanis,2002). The business agility themes in functional context are agile supply chain (Charles, Lauras, \& Wasenhove,2010), IT agility (Pfahl, 2014), HR agility (Gochman \& Storfer,2014), manufacturing agility (Nagel \& Dove, 1991), workforce agility (Breu, Hemingway, Strathern, \& Bridger, 2001), marketing agility (Poolton, Ismail, Reid, \& Arokiam, 2006), value chain agility (Swafford, Ghosh, \& Murthy, 2006), value stream agility (Burgess, Hwarng, Shaw, \& De Mattos, 2002), global risk agility (Wagner \& Disparte, 2016), and sales force agility (Chonko \& Jones, 2005). The business agility themes in the group context are team agility (McManus, 2003) and leadership agility (Joiner \& Josephs, 2007). The business agility themes in individual context are learning agility (Lombardo \& Eichinger, 2000) and culturally agile (Caligiuri, 2013).

This paper uses organizational behavior theory (OBT) as an approach (Robbins \& 
Judge, 2013; Schermerhorn, Hunt, Osborn, \& Uhl-Bien, 2011). OBT explains that the effectiveness of groups or team determines the effectiveness of an organization within the organization. The individual effectiveness of group members determines the effectiveness of the group. Therefore, in elaborating business agility, this paper proposes a multi-layer perspective. Business agility as specific behavior in the business organization is viewed and defined into three different perspectives: (1) strategic agility as the agility in an organizational perspective; (2) leadership agility as the agility in a group perspective; and (3) learning agility as the business agility in an individual perspective. Combining these three different perspectives of business agility could offer the academician and practitioner a new construct to define, measure, and analyze business agility more comprehensively with multi-layer perspectives.

\section{LITERATURE REVIEW}

\section{Strategic agility}

The concept of strategic agility came from the recommendation of the lacocca Institute (Lehigh University). This recommendation was for the United States government in the early 1990 s to improve the competitiveness of the manufacturing industry by developing agile manufacturing (Nagel \& Dove, 1991). Furthermore, agile manufacturing evolves into enterprise agility that integrates organizations, people, and technology throughout the enterprise to deal effectively with a highly competitive environment. The integration needs supporting infrastructure for production, market, people, and information (Tsourveloudis \& Valavanis, 2002).

Based on previous research (Brueller, Carmeli, \& Drori, 2014; Fourné, Jansen, \& Mom, 2014; Junni, Sarala, Tarba, \& Weber, 2015; Subhi Idris \& AL-Rubaie, 2013); strategic agility is defined as "the ability of the organization to be flexible and fast in monitoring opportunities and capturing value through maximizing strength and reconfiguring the organization continuously in order to be sustainable for the long run." Strategic agility is reflected into three dimensions: strategic sensitivity, leadership unity, and resource fluidity (Arbussa,
Bikfalvi, \& Marques, 2017; Doz \& Kosonen, 2010).

Strategic sensitivity is reflected by the ability of top management for knowing the direction of future business quickly, experimenting with best management practice, and encouraging employees to master new skills. Leadership unity is reflected by the ability of top management to identifying the potential of employees quickly, recognizing employee support quickly, and maintaining the unity of direction. Resource fluidity is reflected by the ability of top management in anticipating resource requirements quickly, providing resources quickly, and solving the problem of the business unit quickly.

\section{Leadership agility}

Leadership agility is based on resource orchestration (Sirmon, Hitt, Ireland, \& Gilbert, 2011) and leadership potential (Dries \& Pepermans, 2012) as applied theory. The manager has a strategic role in managing diverse human resources in a highly changing environment. Based on previous studies (Horney, Pasmore, \& O'Shea, 2010; Joiner, 2009; Joiner \& Josephs, 2007; McKenzie \& Aitken, 2012), learning agility is defined as the ability to lead a group of people flexibly and quickly in sensing and responding to business changes as well as the ability to unlearn and relearn about the relevant sources of success. Leadership agility is reflected into four dimensions: self-leadership agility, context-setting agility, stakeholder agility, and creativity agility (Joiner, 2009; Joiner \& Josephs, 2007)

Self-leadership agility is reflected by the ability of direct superior for recognizing personal strength and weakness, developing the competence of the team continuously, and being a role model in selfdevelopment. Context-setting agility is reflected by the ability of direct superior for collecting information from various sources, taking the initiative quickly in complicated situations, and taking appropriately in an uncertain situation. Stakeholder agility is reflected by the ability of direct superior to recognize the interests of influential parties, building relationships with influential parties, and influencing others effectively. Creativity agility is reflected in the ability of direct superior for providing direction quickly, 
encouraging the team to search the creative solution, and being dared to decide.

\section{Learning agility}

Learning agility is believed as the construct for predicting current performance, future potential, and adaptability to a vibrant, dynamic environment (Bedford, 2011; Connolly, 2001; De Meuse, Dai, Hallenbeck, \& Tang, 2008). Learning agility indicates the individual's ability to adapt the relevant lesson learned from the experience into different and more complex contexts (Allen, 2016). Based on Lombardo \& Eichinger (2000) and concern from DeRue, Ashford, \& Myers (2012) to differentiate learning agility from learning ability, this paper defined learning agility as the individual's ability to be flexible and fast leveraging experience to cope with complicated new situations. Learning agility is reflected into four dimensions: change agility, mental agility, people agility, and result agility (Gravett \& Caldwell, 2016).

Change agility is reflected by the personal ability for making the personal experience the learning opportunity, for leasing personal achievement within external obstacles and making workload a challenge. Mental agility is reflected by the personal ability for learning from mistakes quickly, having own style of learning, and enjoying difficulty at work. The result ability reflects individual agility for keeping logical in dealing with a complicated problem, keeping the spirit high in solving the long process of solving a problem, and solving the problem without guidance and support from the others. The people ability reflects people agility for being happy to work with various people, learning from others quickly, and being asked for help by others (PA03). To sum up, appendix A represents the dimensions, indicators, and code for strategic agility, leadership agility, and learning agility.

\section{METHODS}

Supervisors and estate managers of Indonesia palm oil plantations are the respondents of this study. We estimate about 16,000 supervisors and managers as the population. This paper used cluster stratified proportional random sampling for collecting data. Most of Indonesia palm oil plantation (95.8\%) are in Borneo and
Sumatra, the sample was divided into two clusters - Sumatra and Borneo. The sample was stratified proportionally based on structural positions and clusters. Data collection is pick up randomly based on the list of GAPKI members. The expected sample size was 376 (Krejcie \& Morgan, 1970).

This data has collected from 491 respondents, but 14 respondents did not give responses completely. Finally, the analysis of this paper based on 477 respondents. The profile of respondents is dominated by men (85\%); born between 1980 to $1999(79 \%)$; less five year of work experience in palm oil plantation (51\%); with bachelor's degree as educational background $(71 \%)$; come from non-farming family $(80 \%)$, and as team leader or supervisor in the organization (60\%).

Covariance Based SEM approach by utilizing Lisrel version 9.30 was used for data analysis. CB-SEM has robust estimation and is more relevant for confirmatory research than Variance-Based SEM (Hair, Hult, Ringle, \& Sarstedt, 2014). SEM has two main steps: (1) measurement model analysis and (2) structural model analysis. For examining construct validity, this paper utilized confirmatory factor analysis (CFA) of measurement model for evaluating validity of items, reliability of dimension, and goodness of fit of the measurement model. Validity of items are indicated by SFL $>0.5$ (standardized factor loading). Reliability of dimension is indicated by CR more than 0.7 (construct reliability) or VE more than 0.5 (variance extracted). The goodness of fit analysis of the model is indicated by $\mathrm{p}$-value, RMSEA, NFI, NNFI, CFI, RFI, IFI, Standardized RMR, GFI, and AGFI. CFA is conducted on first, second and third order construct of multi-layer agility.

This paper conducted analysis of construct validity by on comparing analysis of measurement model of multi-layer agility in the different constructs: first, second, and third order construct. From three different construct, this paper decided which construct is the best-fit one.

\section{RESULTS AND DISCUSSION}

\section{First order construct}

First order construct is a construct which is directly reflected into the items or indicators. First order construct of multi-layer agility is 
Table 1.

Validity \& reliability test for second order construct

\begin{tabular}{|c|c|c|c|c|}
\hline $\begin{array}{c}\text { Variable } \\
\text { / item }\end{array}$ & $\begin{array}{c}\text { SFL > } \\
0,5\end{array}$ & $\begin{array}{c}\text { CR > } \\
0,7\end{array}$ & $\begin{array}{c}\text { VE > } \\
0,5\end{array}$ & Result \\
\hline \multicolumn{2}{|c|}{ Strategic Agility } & 0,87 & 0,44 & Reliable \\
\hline SS01 & 0,61 & & & Valid \\
\hline SS02 & 0,60 & & & Valid \\
\hline SS03 & 0,67 & & & Valid \\
\hline LU01 & 0,78 & & & Valid \\
\hline LU02 & 0,79 & & & Valid \\
\hline LU03 & 0,76 & & & Valid \\
\hline RF01 & 0,64 & & & Valid \\
\hline RF02 & 0,54 & & & Valid \\
\hline RF03 & 0,52 & & & Valid \\
\hline \multicolumn{2}{|c|}{ Leadership Agility } & 0,94 & 0,57 & Reliable \\
\hline XA01 & 0,59 & & & Valid \\
\hline XA02 & 0,82 & & & Valid \\
\hline XA03 & 0,83 & & & Valid \\
\hline HA01 & 0,78 & & & Valid \\
\hline HA02 & 0,77 & & & Valid \\
\hline HA03 & 0,81 & & & Valid \\
\hline VA01 & 0,82 & & & Valid \\
\hline VA02 & 0,82 & & & Valid \\
\hline
\end{tabular}

\begin{tabular}{|c|c|c|c|c|}
\hline $\begin{array}{l}\text { Variable } \\
\text { / item }\end{array}$ & SFL $>0,5$ & $\begin{array}{c}\text { CR > } \\
0,7\end{array}$ & $\begin{array}{c}\text { VE > } \\
0,5\end{array}$ & Result \\
\hline \multicolumn{2}{|c|}{ Leadership Agility } & 0,94 & 0,57 & Reliable \\
\hline VA03 & 0,58 & & & Valid \\
\hline FA01 & 0,71 & & & Valid \\
\hline FA02 & 0,73 & & & Valid \\
\hline FA03 & 0,79 & & & Valid \\
\hline \multicolumn{2}{|c|}{ Learning Agility } & 0,87 & 0,37 & Reliable \\
\hline CA01 & 0,51 & & & Valid \\
\hline CA02 & 0,63 & & & Valid \\
\hline CA03 & 0,62 & & & Valid \\
\hline MA01 & 0,61 & & & Valid \\
\hline MA02 & 0,62 & & & Valid \\
\hline MA03 & 0,65 & & & Valid \\
\hline PA01 & 0,63 & & & Valid \\
\hline PA02 & 0,69 & & & Valid \\
\hline PA03 & 0,54 & & & Valid \\
\hline RA01 & 0,68 & & & Valid \\
\hline RA02 & 0,55 & & & Valid \\
\hline RA03 & 0,53 & & & Valid \\
\hline
\end{tabular}

shown in appendix B. The multi-layer agility is directly reflected into 33 items or indicators. Standardized factor loading of all items in learning agility (CA01, CA02, CA02, MA01, MA02, MA03, PA01, PA02, PA03, RA01, RA02, RA03) and several items in strategic agility (SS01, SS02, RF01, RF02, RF03) are lower than 0.5. It indicates that all items in learning agility and several items in strategic agility are not valid and these items were excluded from measurement model. The model becomes incomplete and does not reflect an integrated model of business agility in individual, group, and organization anymore. The first order construct of multi agility is not valid for measurement model of multi-layer agility.

\section{Second order construct}

The second order construct is a construct which the variable is reflected into dimensions and then the dimension is reflected into the items. The second order construct of multi-layer agility is shown in appendix C. The multi-layer agility is reflected into three dimensions: strategic agility, learning agility and strategic agility. All items have SFL score more than 0.5. it means that all items of all dimensions are valid as the indicators.

The analysis of reliability is shown in table 1. Construct validity (CR) of all dimensions is more than 0.7. Strategic

agility, leadership agility, and learning agility are reliable as the dimensions of model. The second order construct is the model with valid items, reliable dimensions, and good fit model with RMSEA $=0.064$ or less than 0.08 .

\section{Third order construct}

The third order construct is a construct which variables is defined into dimensions, then dimension is reflected into sub-dimensions and finally the sub-dimension is explained by the items or indicators. The third order construct of multi-layer agility is shown in appendix $D$. The multi-layer agility is reflected into three dimensions: strategic agility, learning agility and strategic agility. Strategic agility is reflected by three subdimensions: strategic sensitivity, leadership unity, and resource fluidity. Leadership agility is reflected by four dimensions: selfleadership agility, context-setting agility, stakeholder agility, and creativity agility. Learning agility is reflected by four subdimensions: change agility, mental agility, people agility, and result agility. Each of sub-dimension is reflected by three items or indicators.

Analysis of validity and reliability is shown on table 2. Standardized factor loading of all items are more than 0.5. All items are valid as the indicator or items. All sub-dimensions of strategic agility and leadership agility are 
Table 2.

Validity \& reliability test for third order construct

\begin{tabular}{|c|c|c|c|c|c|c|c|c|c|}
\hline Dimension/item & $\begin{array}{c}\text { SFL } \\
> \\
0,5\end{array}$ & $\begin{array}{c}\text { CR } \\
> \\
0,7\end{array}$ & $\begin{array}{c}\text { VE } \\
> \\
0,5\end{array}$ & Result & Dimension/item & $\begin{array}{l}\text { SFL } \\
>0,5\end{array}$ & $\begin{array}{c}\text { CR } \\
> \\
0,7\end{array}$ & $\begin{array}{c}\text { VE } \\
> \\
0,5\end{array}$ & Result \\
\hline \multicolumn{5}{|c|}{ Strategic Agility (STRAG) } & \multicolumn{5}{|c|}{ Leadership Agility (LDAG) } \\
\hline \multicolumn{2}{|c|}{$\begin{array}{l}\text { Strategic Sensing } \\
\text { (STS) }\end{array}$} & 0,77 & 0,53 & Reliable & \multicolumn{2}{|c|}{$\begin{array}{l}\text { Self-Leadership Agility } \\
\text { (FAG) }\end{array}$} & 0,83 & 0,63 & Reliable \\
\hline SS01 & 0,72 & & & Valid & FA01 & 0,74 & & & Valid \\
\hline SS02 & 0,73 & & & Valid & FA02 & 0,77 & & & Valid \\
\hline SS03 & 0,73 & & & Valid & FA03 & 0,84 & & & Valid \\
\hline \multicolumn{2}{|c|}{$\begin{array}{l}\text { Leadership Unity } \\
\text { (LEU) }\end{array}$} & 0,85 & 0,65 & Reliable & \multicolumn{5}{|c|}{ Learning Agility (LRAG) } \\
\hline LU01 & 0,81 & & & Valid & \multicolumn{2}{|c|}{ Change Agility (CAG) } & 0,67 & 0,41 & $\begin{array}{c}\text { Not } \\
\text { Reliable }\end{array}$ \\
\hline LU02 & 0,83 & & & Valid & CA01 & 0,51 & & & Valid \\
\hline LU03 & 0,78 & & & Valid & CA02 & 0,71 & & & Valid \\
\hline \multicolumn{2}{|c|}{$\begin{array}{l}\text { Resource Fluidity } \\
\text { (REF) }\end{array}$} & 0,75 & 0,51 & Reliable & CA03 & 0,68 & & & Valid \\
\hline RF01 & 0,74 & & & Valid & Mental Agility & AG) & 0,72 & 0,46 & Reliable \\
\hline RF02 & 0,68 & & & Valid & MA01 & 0,65 & & & Valid \\
\hline RF03 & 0,69 & & & Valid & MA02 & 0,71 & & & Valid \\
\hline \multicolumn{5}{|c|}{ Leadership Agility (LDAG) } & MA03 & 0,69 & & & Valid \\
\hline \multicolumn{2}{|c|}{$\begin{array}{l}\text { Context Setting } \\
\text { Agility (XAG) }\end{array}$} & 0,85 & 0,66 & Reliable & \multicolumn{2}{|c|}{ People Agility (PAG) } & 0,69 & 0,43 & $\begin{array}{c}\text { Not } \\
\text { Reliable }\end{array}$ \\
\hline XA01 & 0,62 & & & Valid & PA01 & 0,66 & & & Valid \\
\hline XA02 & 0,89 & & & Valid & PA02 & 0,74 & & & Valid \\
\hline XA03 & 0,91 & & & Valid & PA03 & 0,55 & & & Valid \\
\hline \multicolumn{2}{|c|}{$\begin{array}{l}\text { Stake-Holder Agility } \\
\text { (HAG) }\end{array}$} & 0,87 & 0,69 & Reliable & \multicolumn{2}{|c|}{ Result Agility (RAG) } & 0,62 & 0,36 & $\begin{array}{c}\text { Not } \\
\text { Reliable }\end{array}$ \\
\hline $\mathrm{HA} 01$ & 0,82 & & & Valid & RA01 & 0,72 & & & Valid \\
\hline HA02 & 0,83 & & & Valid & RA02 & 0,52 & & & Valid \\
\hline HA03 & 0,84 & & & Valid & RA03 & 0,53 & & & Valid \\
\hline \multicolumn{2}{|c|}{$\begin{array}{c}\text { Creativity Agility } \\
\text { (VAG) }\end{array}$} & 0,81 & 0,58 & Reliable & & & & & \\
\hline VA01 & 0,83 & & & Valid & & & & & \\
\hline VA02 & 0,83 & & & Valid & & & & & \\
\hline VA03 & 0,59 & & & Valid & & & & & \\
\hline
\end{tabular}

Table 3.

Goodness of fit analysis

\begin{tabular}{ccccccc}
\hline \multirow{2}{*}{ No. } & \multirow{2}{*}{ GOFI } & \multirow{2}{*}{ Standard } & \multicolumn{2}{c}{ Second order } & \multicolumn{2}{c}{ Third order } \\
\cline { 3 - 6 } & & Score & Result & Score & Result \\
\hline 1 & p-Value & p-Value $>0,050$ & 0,000 & Not & 0,000 & Not \\
2 & RMSEA & RMSEA $\leq 0,080$ & 0,065 & Good Fit & 0,046 & Good Fit \\
3 & NFI & NFI $\geq 0,900$ & 0,873 & Not & 0,908 & Good Fit \\
4 & NNFI & NNFI $\geq 0,900$ & 0,922 & Good Fit & 0,959 & Good Fit \\
5 & CFI & CFI $\geq 0,900$ & 0,927 & Good Fit & 0,962 & Good Fit \\
6 & IFI & IFI $\geq 0,900$ & 0,927 & Good Fit & 0,963 & Good Fit \\
7 & RFI & RFI $\geq 0,900$ & 0,865 & Not & 0,899 & Good Fit \\
& Standardized & Standardized RMR & & & & \\
8 & RMR & $<0,050$ & 0,059 & Not & 0,054 & Not \\
9 & GFI & GFI $\geq 0,900$ & 0,811 & Not & 0,871 & Not \\
10 & AGFI & AGFI $>0,900$ & 0,705 & Not & 0,849 & Not \\
\hline
\end{tabular}

reliable. But only mental agility (MAG) is reliable. Three dimensions of learning agility - change agility (CAG), people agility (PAG), and result agility (RAG) are not reliable. The third order construct of multi-layer agility is not good model, because not all dimensions are reliable. The goodness of fit analysis of second and third construct is shown in table 
3. The third order construct has five indexes - RMSEA, NFI, NNFI, CFI, and IFI - that indicate good fit. The second order construct has four indexes - RMSEA, NNFI, CFI, and IFI that indicate good fit. Based on goodness of fit analysis, the third order is better than the second one. Although third order construct has better goodness of fit than second order, but third order construct has some dimensions which is not reliable. Therefore, second order construct is considered better as a measurement model because it has valid items, a reliable dimension and a good fit model.

\section{CONCLUSION}

For being able to adapt quickly, even faster than the change itself, the companies in Indonesia palm oil plantation should develop agility in whole layer of organization. Multi-layer agility provides the concept of integrated agility in individual, group, and organizational perspective. For measuring the multi-layer agility in organization, this paper recommends second order construct. It means that multi-layer agility is reflected into strategic agility, leadership agility, and learning agility and then all dimensions are reflected into its items.

The second order construct is best-fit construct for defining, measuring, and analyzing multi-layer agility; because all items are valid, all dimensions are reliable, and the model has enough goodness of fit.

For further research on construct validity of multi-layer agility, this paper recommends to utilize Rasch Model or Item Response Theory which provide better analysis for the items of the proposed variable.

\section{REFERENCES}

Allen, J. (2016). Conceptualizing learning agility and investigating its nomological network. Florida International University.

Arbussa, A., Bikfalvi, A., \& Marques, P. (2017). Strategic agility driven business model renewal: The case of an sme. Management Decision, 55(2). http://doi.org/10.1108/MD-05-20160355

Bawany, S. (2016). Leading in a VUCA business environment. Leadership Excellence Essentials, 07, 39-40.

Bedford, C. L. (2011). The role of learning agility in workplace performance and career advancement. University of Minnesota.
Breu, K., Hemingway, C. J., Strathern, M., \& Bridger, D. (2001). Workforce agility: the new employee strategy for the knowledge economy. Journal of Information Technology, 17, 21-31.

Brown, J. L., \& Agnew, N. M. K. (1982). Corporate agility. Business Horizons, 25(2), 29-33. http://doi.org/10.1016/00076813(82)90101-X

Brueller, N. N., Carmeli, A., \& Drori, I. (2014). How do different types of mergers and acquisitions facilitate strategic agility? California Management Review, 56(3), 39-58.

Burgess, T., Hwarng, B., Shaw, N., \& De Mattos, C. (2002). Enhancing value stream agility: The UK speciality chemical industry. European Management Journal, 20(2), 199-212.

Caligiuri, P. (2013). Developing culturally agile global business leaders. Organizational Dynamics, 42(3), 175-182.

Cannon, F., \& Elford, N. (2017). The agility mindset: How reframing flexible working delivers competitive advantage. Palgrave MacMillan.

Charles, A., Lauras, M., \& Wasenhove, L. Van. (2010). A model to define and assess the agility of supply chains: Building on humanitarian experience. International Journal of Physical Distribution \& Logistics Management, 40(8/9), 727741.

Chonko, L. B., \& Jones, E. (2005). The need for speed: Agility selling. Journal of Personal Selling and Sales Management, XXV(4), 371-382.

Connolly, J. (2001). Assessing the construct validity of a measure of learning agility. Saturday Review. Florida International University.

Crocitto, M., \& Youssef, M. (2003). The human side of organizational agility. Industrial Management \& Data Systems, 103(6), 388-397.

Derue, D. S., Ashford, S. J., \& Myers, C. G. (2012). Learning Agility: In Search of Conceptual Clarity and Theoretical Grounding. Industrial and Organizational Psychology, 5(3), 258279.

Doz, Y. L., \& Kosonen, M. (2010). Embedding strategic agility: A leadership agenda for accelerating business model renewal. Long Range Planning, 43(2-3), 370382. 
Dries, N., \& Pepermans, R. (2012). How to identify leadership potential: Development and testing of a consensus model. Human Resource Management, 51(3), 361-385. http://doi.org/10.1002/hrm.21473

Evans, N. D. (2002). Business agility: Strategies for gaining competitive advantage through mobile business solutions. Prentice Hall.

Fourné, S. P. L., Jansen, J. J. P., \& Mom, T. J. M. (2014). Strategic agility in MNEs: Managing tensions to capture opportunities across emerging and established markets. California Management Review, 56(3), 13-38.

Glauner, F. (2016). Future viability, Business models and values.

Gochman, I., \& Storfer, P. (2014). Talent for tomorrow: Four Secrets for HR Agility in an Uncertain World. People \& Strategy, $37(2), 25$

Gravett, L. S., \& Caldwell, S. A. (2016). What is Learning Agility? In Learning Agility (pp. 1-8). Palgrave Macmillan, New York.

Hair, J. F. J., Hult, G. T. M., Ringle, C., \& Sarstedt, M. (2014). A primer on partial least squares structural equation modeling (PLS-SEM). Long Range Planning. http://doi.org/10.1016/j.Irp.2013.01.002

Heisterberg, R., \& Verma, A. (2014). Creating business agility: How convergence of cloud, social, mobile, video and big data enables competitive advantage. Hoboken - New Jersey: John Wiley \& Son, Inc.

Horney, N., Pasmore, B., \& O'Shea, T. (2010). Leadership agility: A business imperative for a VUCA World. People \& Strategy, 32-38.

Hugos, M. H. (2009). Business agility: Sustainable prosperity in a relentlessly competitive world (Microsoft Executive Leadership Series).

Joiner, B. (2009). Creating a culture of agile leaders: A developmental approach. People \& Strategy, 32(4), 28-35.

Joiner, B., \& Josephs, S. (2007). Developing agile leaders. Industrial \& Commercial Training, 39(1), 35-42.

Junni, P., Sarala, R. M., Tarba, S. Y., \& Weber, Y. (2015). The role of strategic agility in acquisitions. British Journal of Management, 26(4), 596-616.

Krejcie, R. V, \& Morgan, D. (1970). Determining Sample Size for Research Activities.
Educational and Psychological Measurement, 30, 607-610.

Lombardo, M. M., \& Eichinger, R. W. (2000). High potentials as high learners. Human Resource Management, 39(4), 321329.

Mack, O., \& Khare, A. (2015). Perspectives on a VUCA world. In Managing in a VUCA World (pp. 3-19).

McCann, J., Selsky, J., \& Lee, J. (2009). Building Agility, Resilience and Performance in Turbulent Environments. People \& Strategy, 32(3), 44-51.

McCann, J., \& Selsky, J. W. (2012). Mastering Turbulence: The Essential Capabilities of Agile and Resilient Individuals, Teams and Organizaitons. Jossey-Bass.

McKenzie, J., \& Aitken, P. (2012). Learning to lead the knowledgeable organization: developing leadership agility. Strategic HR Review, 11(6), 329-334. http://doi.org/10.1108/14754391211264 794

McManus, J. (2003). Team agility. The Computer Bulletin, (September), 26-27.

Meuse, K. De, Dai, G., Hallenbeck, G., \& Tang, K. (2008). Using Learning agility to identify high potentials around the world. Korn/Ferry Institute. http://doi.org/10.1037/e562502013-001

Murthy, V., \& Murthy, A. (2014). Adaptive leadership responses: Introduction to an emerging classification of zitgeist enactments, practices and virtues for a VUCA world. World Journal of Entrepreneurship, Management and Sustainable Development, 10(3), 162176. http://doi.org/10.1108/WJEMSD05-2013-0029

Nagel, R. N., \& Dove, R. (1991). 21st century manufacturing enterprise strategy: An industry-led view. laccocca Institute of Lehigh University.

Pfahl, D. (2014). Lecture 11: Agile/Lean Methods Schedule of Lectures Structure of Lecture 11, 1-12.

Poolton, J., Ismail, H. S., Reid, I. R., \& Arokiam, I. C. (2006). Agile marketing for the manufacturing-based SME. Marketing Intelligence \& Planning, 24(7), 681-693. http://doi.org/10.1108/02634500610711 851

Robbins, S. P., \& Judge, T. A. (2013). Essential of Organizational Behavior (12th ed.). Pearson. 
Schermerhorn, J. R., Hunt, J. G., Osborn, R. N., \& Uhl-Bien, M. (2011). Organizational behavior (Vol. 11th, Int).

Sirmon, D. G., Hitt, M. A., Ireland, R. D., \& Gilbert, B. A. (2011). Resource Orchestration to Create Competitive Advantage: Breadth, Depth, and Life Cycle Effects. Journal of Management, 37(5), 13901412.

Subhi Idris, W. M., \& AL-Rubaie, M. T. K. (2013). Examining the Impact of Strategic Learning on Strategic Agility. Journal of Management and Strategy, 4(2), p70. http://doi.org/10.5430/jms.v4n2p70

Swafford, P. M., Ghosh, S., \& Murthy, N. N. (2006). A framework for assessing value chain agility. International Journal of Operations \& Production Management, 26(2), 118-140.

Tsourveloudis, N. C., \& Valavanis, K. P. (2002). On the Measurement of Enterprise Agility. Journal of Intelligent and Robotic Systemes, 33, 329-342.

Wagner, D., \& Disparte, D. (2016). Global risk agility and decision making. Palgrave MacMillan. http://doi.org/10.1057/978-1349-94860-4

Light, M. A., \& Light, I. H. (2008) The geographical expansion of Mexican immigration in the United States and its implication for local law enforcement. Law Enforcement Executive Forum Journal, 8(1), 73-82. 
Appendix A.

Dimensions, indicators, and code for strategic, leadership, and learning agility

\begin{tabular}{|c|c|c|c|c|c|}
\hline Dimension & Indicators & Code & Dimension & Indicators & Code \\
\hline & Strategic Agility & & \multirow{4}{*}{$\begin{array}{l}\text { Self- } \\
\text { leadership } \\
\text { agility }\end{array}$} & Leadership Agility & \\
\hline \multirow{3}{*}{$\begin{array}{l}\text { Strategic } \\
\text { sensitivy }\end{array}$} & $\begin{array}{l}\text { The ability of top management } \\
\text { for knowing the direction of } \\
\text { future business quickly }\end{array}$ & SS01 & & $\begin{array}{l}\text { The ability of direct superior for } \\
\text { recognizing personal strength } \\
\text { and weakness }\end{array}$ & FA01 \\
\hline & $\begin{array}{l}\text { The ability of top management } \\
\text { for experimenting with best } \\
\text { management practice }\end{array}$ & SS02 & & $\begin{array}{l}\text { The ability of direct superior for } \\
\text { developing the competence of } \\
\text { the team continuously }\end{array}$ & FA02 \\
\hline & $\begin{array}{l}\text { The ability of top management } \\
\text { for encouraging employees to } \\
\text { master new skills }\end{array}$ & SS03 & & $\begin{array}{l}\text { The ability of direct superior for } \\
\text { being a role model in self- } \\
\text { development }\end{array}$ & FA03 \\
\hline \multirow{3}{*}{$\begin{array}{l}\text { Leadership } \\
\text { unity }\end{array}$} & $\begin{array}{l}\text { The ability of top management to } \\
\text { identifying the potential of } \\
\text { employees quickly }\end{array}$ & LU01 & \multicolumn{3}{|c|}{ Learning agility } \\
\hline & $\begin{array}{l}\text { The ability of top management to } \\
\text { recognizing employee support } \\
\text { quickly }\end{array}$ & LU02 & \multirow{3}{*}{$\begin{array}{l}\text { Change } \\
\text { agility }\end{array}$} & $\begin{array}{l}\text { The individual ability for making } \\
\text { the personal experience the } \\
\text { learning opportunity }\end{array}$ & CA01 \\
\hline & $\begin{array}{l}\text { The ability of top management to } \\
\text { maintaining the unity of direction }\end{array}$ & LU03 & & $\begin{array}{l}\text { The individual ability for for } \\
\text { leasing personal achievement } \\
\text { within external obstacles }\end{array}$ & CA02 \\
\hline \multirow{4}{*}{$\begin{array}{l}\text { Resource } \\
\text { fluidity }\end{array}$} & $\begin{array}{l}\text { The ability of top management in } \\
\text { anticipating resource } \\
\text { requirements quickly }\end{array}$ & RF01 & & $\begin{array}{l}\text { The individual ability for making } \\
\text { workload a challenge }\end{array}$ & CA03 \\
\hline & $\begin{array}{l}\text { The ability of top management in } \\
\text { providing resources quickly }\end{array}$ & RF02 & \multirow{3}{*}{$\begin{array}{l}\text { Mental } \\
\text { agility }\end{array}$} & $\begin{array}{l}\text { The individual ability for } \\
\text { learning from mistakes quickly }\end{array}$ & MA01 \\
\hline & $\begin{array}{l}\text { The ability of top management in } \\
\text { solving the problem of the } \\
\text { business unit quickly }\end{array}$ & RF03 & & $\begin{array}{l}\text { The individual ability for having } \\
\text { own style of learning }\end{array}$ & MA02 \\
\hline & Leadership agility & & & $\begin{array}{l}\text { The individual ability for } \\
\text { enjoying difficulty at work }\end{array}$ & MA03 \\
\hline \multirow{3}{*}{$\begin{array}{l}\text { Context- } \\
\text { setting } \\
\text { agility }\end{array}$} & $\begin{array}{l}\text { The ability of direct superior for } \\
\text { collecting information from } \\
\text { various sources }\end{array}$ & XA01 & \multirow{3}{*}{$\begin{array}{l}\text { People } \\
\text { agility }\end{array}$} & $\begin{array}{l}\text { The individual agility for being } \\
\text { happy to work with various } \\
\text { people }\end{array}$ & PA01 \\
\hline & $\begin{array}{l}\text { The ability of direct superior for } \\
\text { taking the initiative quickly in } \\
\text { complicated situations }\end{array}$ & XA02 & & $\begin{array}{l}\text { The individual agility for } \\
\text { learning from others quickly }\end{array}$ & PA02 \\
\hline & $\begin{array}{l}\text { The ability of direct superior for } \\
\text { taking appropriately in an } \\
\text { uncertain situation }\end{array}$ & XA03 & & $\begin{array}{l}\text { The individual agility for being } \\
\text { asked for help by others }\end{array}$ & PA03 \\
\hline \multirow{3}{*}{$\begin{array}{l}\text { Stakeholder } \\
\text { agility }\end{array}$} & $\begin{array}{l}\text { The ability of direct superior to } \\
\text { recognize the interests of } \\
\text { influential parties }\end{array}$ & HA01 & \multirow{3}{*}{$\begin{array}{l}\text { Result } \\
\text { agility }\end{array}$} & $\begin{array}{l}\text { The individual agility for } \\
\text { keeping logical in dealing with } \\
\text { a complicated problem } \\
\text { The individual agility for }\end{array}$ & RA01 \\
\hline & $\begin{array}{l}\text { The ability of direct superior to } \\
\text { building relationships with } \\
\text { influential parties }\end{array}$ & HA02 & & $\begin{array}{l}\text { keeping the spirit high in } \\
\text { solving the long process of } \\
\text { solving a problem }\end{array}$ & RA02 \\
\hline & $\begin{array}{l}\text { The ability of direct superior to } \\
\text { influencing others effectively }\end{array}$ & HA03 & & $\begin{array}{l}\text { The individual agility for solving } \\
\text { the problem without guidance } \\
\text { and support from the others }\end{array}$ & RA03 \\
\hline \multirow{3}{*}{$\begin{array}{l}\text { Creativity } \\
\text { agility }\end{array}$} & $\begin{array}{l}\text { The ability of direct superior for } \\
\text { providing direction quickly }\end{array}$ & VA01 & & & \\
\hline & $\begin{array}{l}\text { The ability of direct superior for } \\
\text { encouraging the team to search } \\
\text { the creative solution }\end{array}$ & VA02 & & & \\
\hline & $\begin{array}{l}\text { The ability of direct superior for } \\
\text { being dared to decide }\end{array}$ & VA03 & & & \\
\hline
\end{tabular}


Appendix B.

First order construct of multi-layer agility

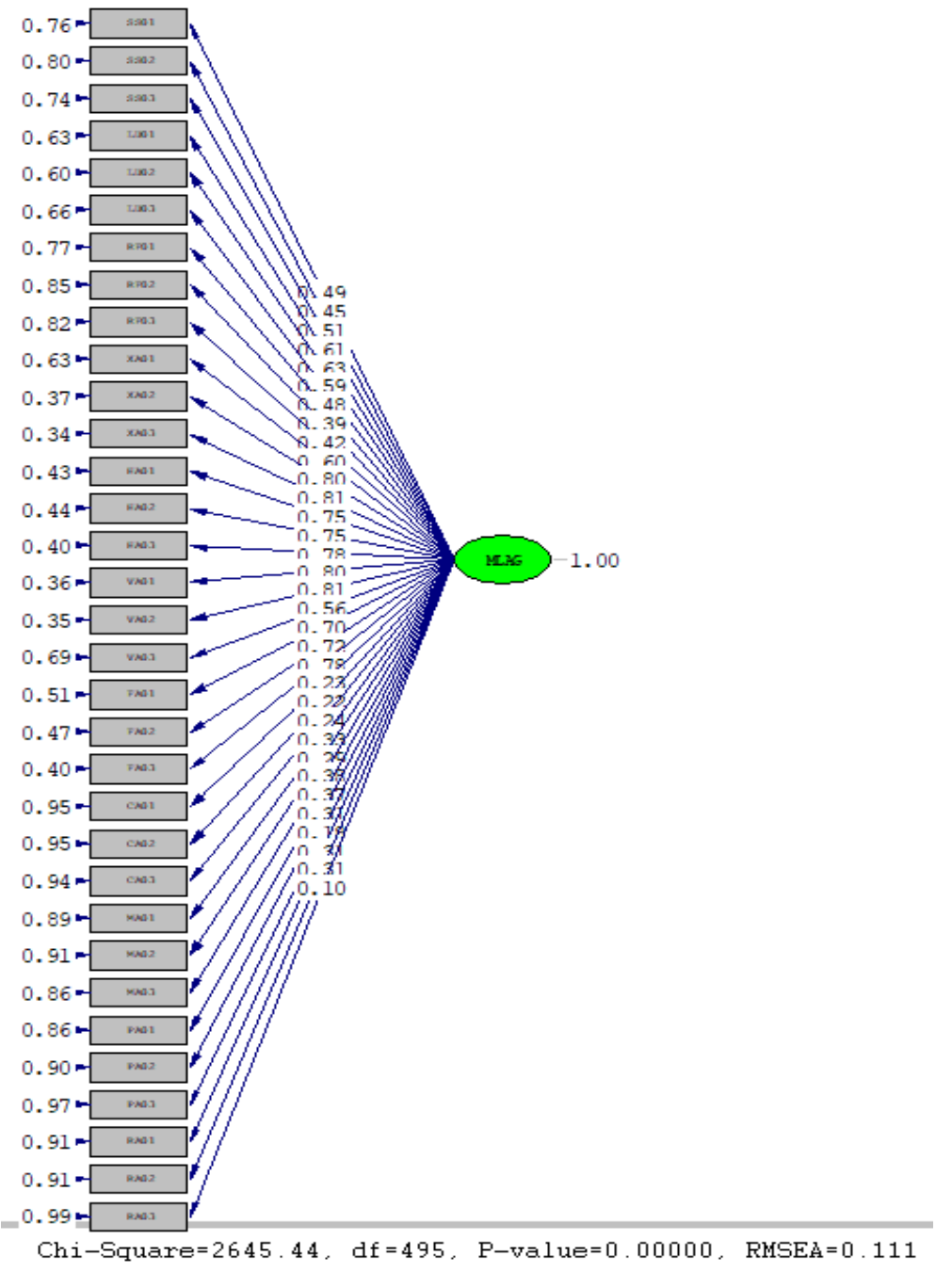


Appendix C.

Second order construct of multi-layer agility

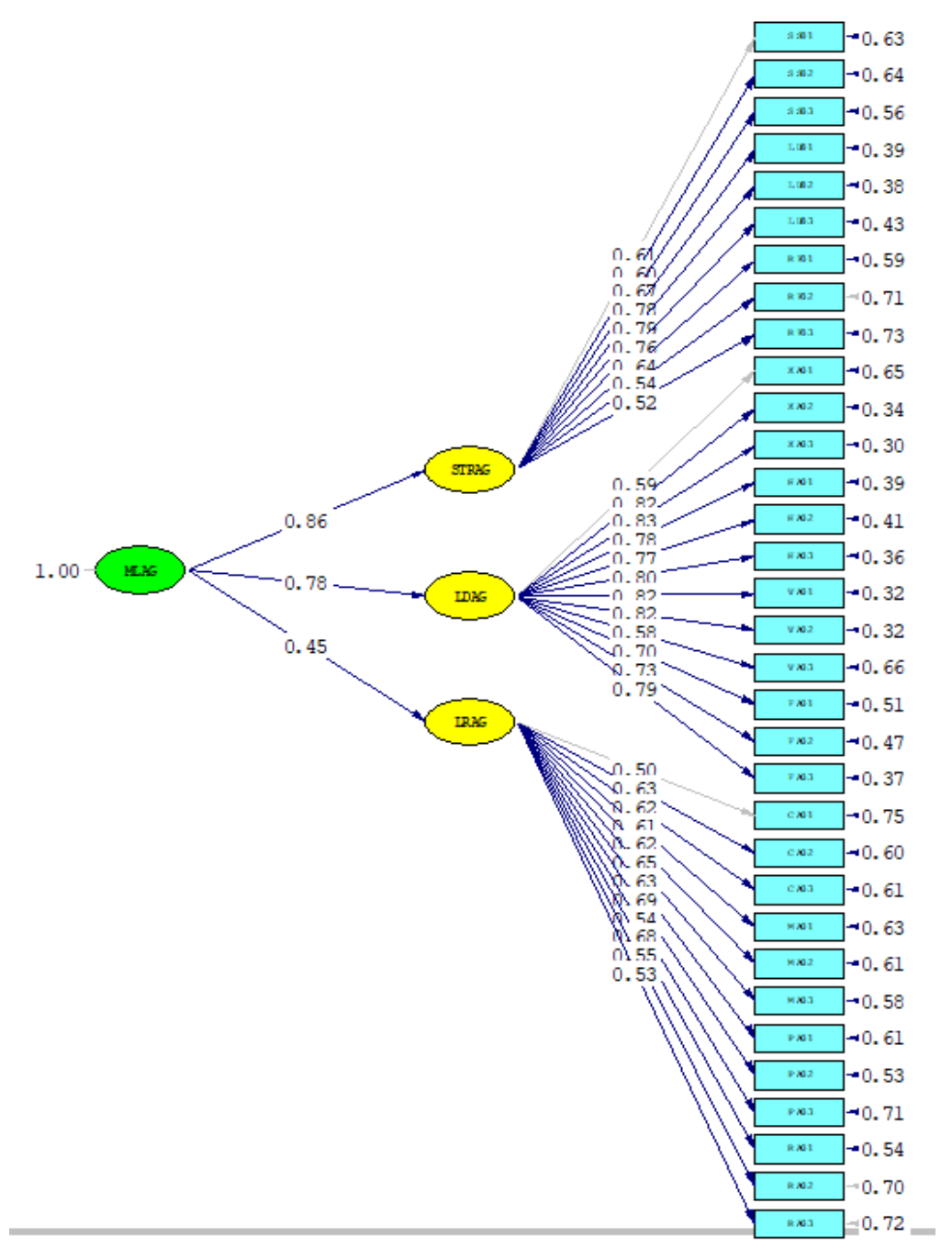

Chi-Square $=1078.05, d f=495, P-v a l u e=0.00000, \quad$ RMSEA $=0.064$ 
Appendix D.

\section{Third order construct of multi-layer agility}

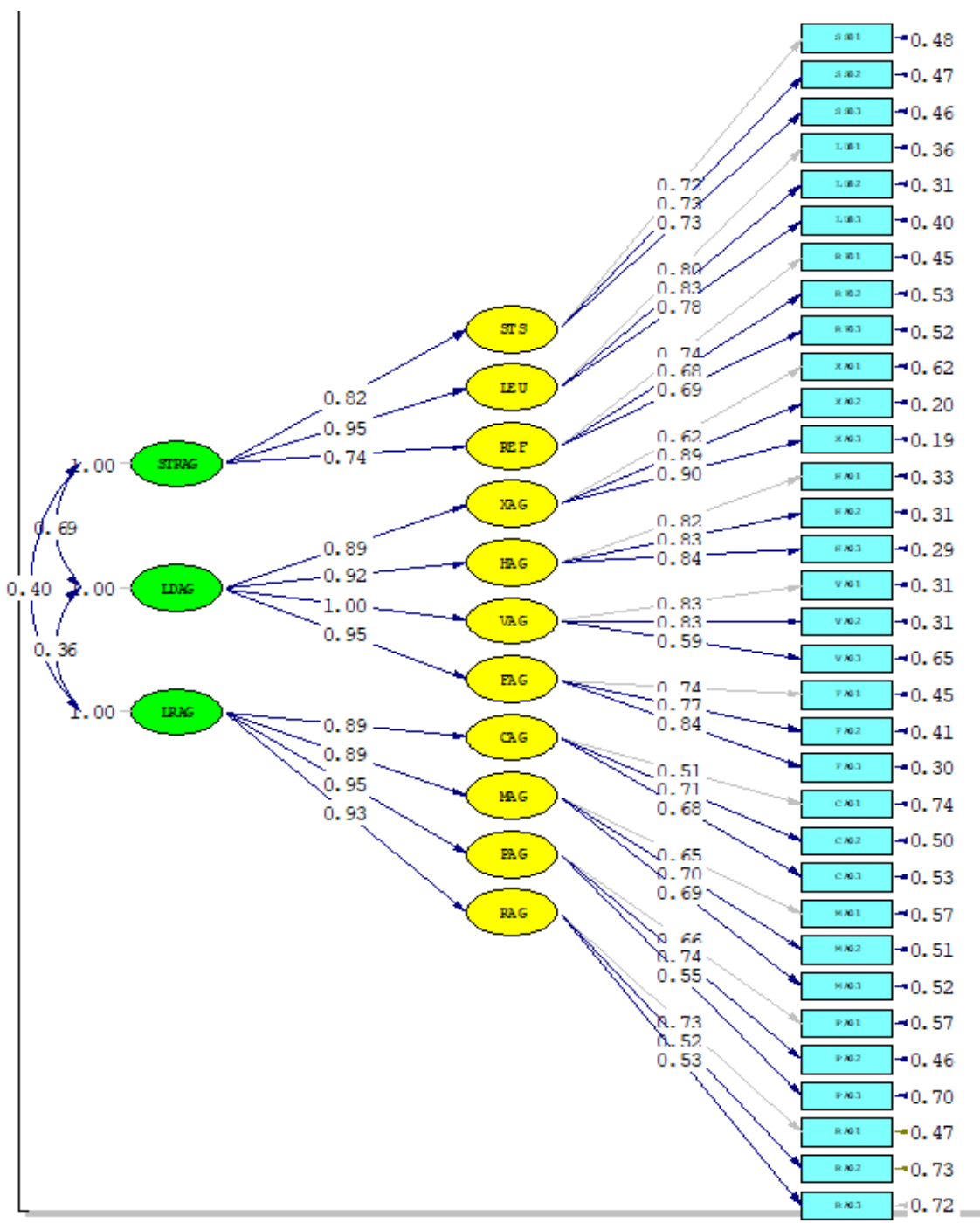

Chi-Square $=754.58, \mathrm{df}=482, \mathrm{P}-\mathrm{value}=0.00000$, RMSEA $=0.046$ 